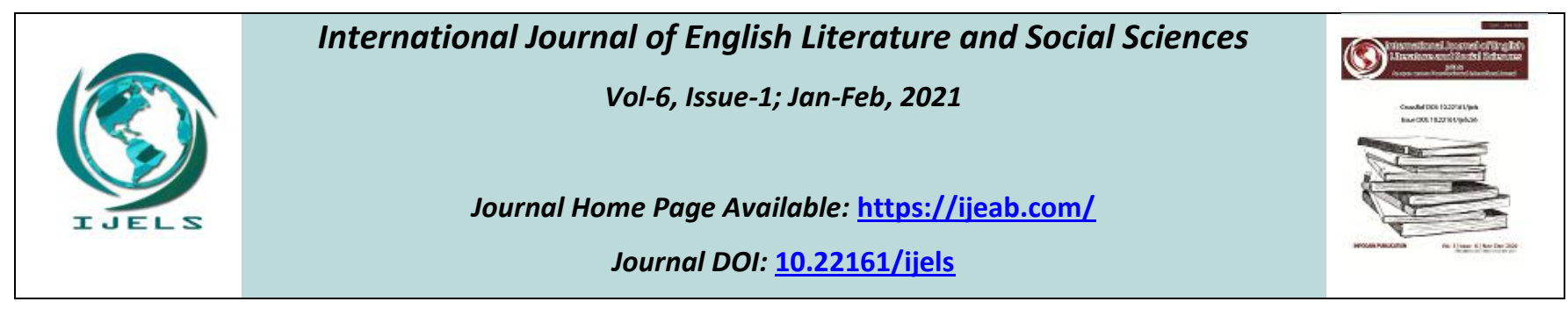

\title{
Performance of Physical Activity of Reog Players as an Art in Indonesia
}

\author{
Ilham Tito Herfino*, Sugiyanto, Hanik Liskustyawati
}

\author{
Department of Sports Science, Postgraduate Program, Sebelas Maret University (UNS), Indonesia \\ Jalan Ir. Sutami No. 36A, Jebres, Kota Surakarta, Central Java, post code:57126, Indonesia. \\ *Corresponding Author
}

Received: 28 Oct 2020; Received in revised form: 25 Dec 2020; Accepted: 04 Jan 2021; Available online: 11 Jan 2021 (C)2021 The Author(s). Published by Infogain Publication. This is an open access article under the CC BY license (https://creativecommons.org/licenses/by/4.0/).

\begin{abstract}
Reog Ponorogo is a traditional art related to physical activities. In the traditional art of Reog Ponorogo, there are sports values namely physical endurance. This study aims to describe the physical activity, form of physical exercise, and mental players of Reog Ponorogo. This research was conducted at Paguyuban Sanggar Seni AGLAR Reog Simo Aglar Nuswantoro and Paguyuban Reog Cokro Menggolo East Java. The research method used is descriptive qualitative. Data collection techniques in the form of observation, interviews, and recording documentation. The results show that physical activity in Reog Ponorogo included a) singo barong: kebat, sembahan, ukel, kayang, rolls, kipu; b) bujang ganong: plugs, somersaults / roll, somersaults, cartwheels, kayang; c) klana sewandhana: kiprahan, counting bolo; d) warok: jengkeng, perangan, fighting lines, sorogompo, ecenan, koloran, the earth, pencakan, lumaksana; e) jathil: lampah telu, gedruk, egol; f) senggakan: voice power, processing vocals and g). pengawit: beat, beat, blow. Forms of physical and mental training for Reog Ponorogo players include: a) singo barong: weight training, neck springs, push ups, pull ups, back ups, sit ups, running; b) bujang ganong: push up, handstand, sit up, back up, run, jump rope, floor exercise; c) klana sewandhana: push up, sit up, back up, run, jump rope; d) warok: push up, sit up, back up, running, jumping rope, floor exercise, pencak silat; e) jathil: horses, jumping rope; f) senggakan: vocals; g) pengrawit: push up keplok, blowing the slompret.
\end{abstract}

Keywords - reog ponorogo physical activity, traditional arts, sporting values.

\section{INTRODUCTION}

Art in society is a means that can be used as a way to express a sense of beauty from within the human soul. Art comes from the Sanskrit language which means offering, service and giving. According to Rima Yuliastuti (2009), the word art comes from the Dutch language, genie which in Latin is called genius, which means extraordinary abilities that are carried from birth. Art can also be associated with sports. Especially art which contains elements of motion. In general, movements in art can be categorized into two types, namely meaningful movements and pure movements. Meaningful motion is movement that expresses meaning explicitly. Meaningful movements, for example, the movement of a person hitting, the movement of a person crying and the movement of an angry person. Pure motion is a movement whose function is only for beauty or does not contain a specific purpose.

In general, the definition of exercise is as a person's physical and psychological activity which is useful for maintaining and improving the quality of one's health after exercise. Sport is an activity that can be enjoyed by all people in the world, regardless of the stratification of a person's level of wealth or poverty. Krisyanto (2012) states that recreational sports are closely related to leisure activities where people are free from work. Sport has the ability to create a feeling that a person belongs to a group or community that loves healthy living and culture. Regular exercise not only keeps the body 
healthy and away from various diseases, but exercise also helps in the process of forming characteristics in society.

The dynamics of sports and value development are positive media to develop the values of life and life, one of which is to develop cultural arts values. In the development of sports until now it has expanded and has universal and unique meanings. Starting from just a physical activity that nourishes the body, filling spare time, and a medium for self-existence, it finally shifts to a multicomplex activity, has influenced and been influenced by other phenomena such as politics, economy, social, art and culture. As a global phenomenon, sport is proven to play an important role in influencing and being influenced by these aspects. Sports can affect various aspects of the value of life and human life, both as individuals and as a society, such as economic, social, cultural, moral, political, educational, and so on.

Taking place of sports activities is closely related to socio-cultural and artistic issues in society. As a developing human being is part of the art work of moving the community in groups and forming cultural arts. This is in line with its development, sports will continue to experience developments in accordance with cultural developments. Nowadays, the development of cultural arts in sports, there are many artistic phenomena that affect the dynamics of social-cultural interactions in society. The relationship between art and sport itself appears in the events of relations between communities which are based on traditions, culture, norms and systems in the local environment.

Indonesia has a regional art called Reog Ponorogo. Reog Ponorogo is one of the traditional arts originating from northwestern East Java and Ponorogo. The traditional arts of Reog Ponorogo prioritize elements of local culture, which are still very strong with mystical things and strong mysticism. This reog art has existed since the time of our ancestors and continues to develop following the times. This development includes both in terms of equipment, clothing accessories, and performance. However, there are some basic things that have not changed. This is done to maintain the characteristics of the traditional Reog Ponorogo art as a local culture.

Reog art is an art that requires physical activity. According to Sajoto (1995) physical condition is a complete unit of components that cannot be separated, either improvement or maintenance. This means that in an effort to improve physical conditions, all these components must develop. Physical ability is very important to support developing psychomotor activities. Skilled body movements can be done if the physical ability is adequate.
Physical endurance, of course, must be possessed by a reog player, especially pembarong or people who play the dhadhak merak. In this section the barongan will act with the dhadak merak mask with teeth. Pembarong with great physical abilities and capable motor movements will certainly be able to provide an interesting spectacle. They kept moving around the barongan as if without a burden, even though the barongan was quite heavy. The weight of this mask can reach 50-60 kg. Sometimes the barongan was climbed by someone, sat on the head of the tiger and was taken around the arena.

The connection with the values of sports as one of the phenomena of the physical activity of the reog players, the traditional arts of Reog Ponorogo are closely related to the development of traditional cultural arts of the local community, here the people of Ponorogo are physically and mentally healthy. This is the formation of the development of the art of motion with one's physical ability to play the reog art without leaving the beauty of movement and the social message contained therein.

The basis of the traditional arts of Reog Ponorogo is the role of the aspects of movement related to sports or physical activities performed by Reog players with wiraga, wirama, and wiraga skills. In the traditional art of Reog Ponorogo, there is movement art which contains sports values. One of the sports values that is always inherent in Reog Ponorogo is the element of physical endurance. Traditional art has something to do with sports as a phenomenon of physical activity performed by Reog players, so what will be examined in the writing of this article is the phenomenon of physical activity of Reog players as traditional arts and training in order to form the physical and mental form of Reog Ponorogo players.

\section{RESEARCH METHOD}

Method used in this research is qualitative descriptive research, which is trying to get information and explain the physical activity phenomena of the traditional arts players Reog Ponorogo. According to Donald Ary (2010) qualitative research is trying to understand phenomena by focusing on the overall picture on solving them into variables. The aim is a holistic overview and depth of understanding rather than numerical analysis of data. This research describes existing conditions or relationships, namely current practices, beliefs, points of view or attitudes, namely ongoing processes, and current influences or developing trends.

The selection of this qualitative method was carried out with the consideration that the focus of this study was a phenomenological study of the physical activity of the Reog players as a traditional art of Reog 
Ponorogo, East Java, using a qualitative descriptive design method which would later be more relevant. According to Moleong (2017) a qualitative approach is research that intends to understand the phenomena experienced by research subjects such as behavior, perception, motivation, and action. This understanding is carried out holistically and by describing it in the form of words and language.

The data collection technique used in this research was non-test which consisted of interviews (interviews, questionnaires), documentation, observation, and sociograms. Data collection was done by triangulating data through observation studies, interviews, and documentation. The data analysis technique in this study used descriptive qualitative data analysis techniques. The qualitative descriptive analysis is used to analyze data by describing or describing the data that has been collected as it is without intending to make general conclusions or generalizations (Sugiyono, 2016). The data obtained were then analyzed through four stages, namely: 1) the data collection stage, 2) the data reduction stage, 3) the data presentation stage, 4) the conclusion / verification stage.

\section{RESULTS AND DISCUSSION}

Descriptive analysis of research results is an analysis of data obtained from interviews with informants, observations and documentation.

\section{Physical Activity of Reog Ponorogo Players Physical activity of Reog Ponorogo}

Players are any form of activity or a variety of physical movements that are carried out with fittings or without tools starting from the beginning of the show until the end of the show. The Reog Ponorogo show is classified into two types of physical activity based on the existing events, namely the Reog Objectok and the Reog festival. The two events have differences, namely in the movement activities carried out. In the Reog Benda show, you may display a variety of physical activity movements in accordance with the wishes of the Reog player or the types of movements that are controlled. Then at the Reog festival performance, it is mandatory to display a variety of movements or physical activities in accordance with standard regulations or festival standards.

There are several forms of physical activity that reog players usually do in their performances. Each player has different forms of physical activity, according to the character and role that is performed. Then the benefits or uses of physical activity or the variety of movements for each player are adjusted to the character and role played. The first is a form of physical activity or a variety of movements for singo barong or dhadak merak players, then bujang ganong, klana sewandana, warok, jathil, senggakan, and the last is pengrawit.

\section{A. Singo Barong or Dhadak Merak}

The form of physical activity or the variety of movements in the performed by each pembarong with different styles, according to the physical abilities possessed by each individual. However, the movements or forms of physical activity that are performed still refer to the types of movements that are commonly performed, in the context of adapting to the character's own character. The singo barong or dhadak merak character is the embodiment of the tiger and peacock, so that the various movements or forms of physical activity automatically mimic the characteristics of the two animals. The forms of physical activity in singo barong or dhadak peacock players that are commonly done are as follows:

\section{1) Kebat}

Kebat is a depiction of the movements performed by male peacocks when showing off the beauty of their feathers in front of female peacocks by developing their tails and circling them.

2) Sembahan

Sembahan is a description of the character and character of singo barong or peacock. This movement is purely an attractive move which aims to show off the strength and skill of the pemarong in performing the dhadak merak dance. This movement is performed by the pemarong with an emphasis on strength and balance. The form of motion in the worship is the movement of lowering or turning the peacock face forward with the body bent and the legs remain upright. As soon as the dhadak merak is facedown to the ground, the pemarong raises the dhadhak merak to its usual position (standing upright).

3) Ukel

Ukel is a movement that is supported by hand movements and playing the cloth covering the body.

4) Kayang 
Kayang has the same goal as prayer. This attractive movement is performed with the aim of showing off the flexibility and strength of the pembarong's body when performing the peacock dhadak dance. This movement is performed by the pemarong by bending the body backwards so that the peacock suddenly touches the floor with both feet. After a while the peacock suddenly pulled back up.

5) Roll

The rolling movement is a depiction of the tiger's character as it rolls on the ground to get rid of fleas or get rid of itching on its body. The motion of dropping the body then lying on its back and rotating the body with the cross leg position ends in a squatting position.

6) Кіри

Кipu is a description of the behavior of a peacock when bathing the ground. This behavior is done so that the peacock is free from lice and relieves itching on its body. The embodiment of this motion is performed by the pembarong in a supine position and the peacock dhadak is above the pembarong.

\section{B. Bujang Ganong}

1) Colotan

Colotan is a motion to lift one leg then rotate a little jump and do it alternately.

2) Tipping Walik

One of the acrobatic attractions that are usually performed by rolling the body forward (front roll or back roll).

3) Salto

One of the acrobatic stunts that is usually performed by turning the body 360 degrees in the air without touching the ground forward or backward.

4) Wheeling

Movements that lead to the side from right to left or vice versa, using your hands as support and opening your legs as wide as possible.

5) Kayang

Movement with both hands and feet resting on the ground in an inverted position then stretching and lifting the pelvis and abdomen up.

\section{6) Klana Sewandana}

a. Kiprahan

Kiprahan is depicting a king in love. In the performance, it is depicted by rolling movements, tumpang rope, trecetan, gastric ogek, slashing the earth according to the drum pattern of

b. Ngitung Bolo

Ngitung bolo is pointing to the audience as counting using the index finger of the right arm and the left arm of malangkerik.

7) Warok

a. Jengkeng

Jengkeng is half sitting on the right knee and left foot, followed by the palm of the right arm touching the ground and the left hand malangkerik.

b. Perangan

A pair of movements to hit the opponent with the right hand clenched in a fist followed by right footsteps.

c. Line fighting

One of the fighting movements performed in pairs with the malangkerik hands.

d. Sorogompo

The movement is pushing each other using both hands in a standing position.

e. Ecenan

The movement is performed in pairs with the position of one jengkeng dancer and one dancer standing malangkerik and laughing out loud which depicts contempt.

f. Koloran The

Movement of the two dancers moving the chest rope or an X-shaped kolor.

g. Motion of the bumi langit

Motion that moves the dadung rope up and down.

h. Pencakan 
Movement which is taken from the movement of pencak parrying or attacking with the hands or feet.

i. Lumaksana (Warok Tua)

A walking motion with the right hand carrying a stick and the left hand holding the drawstring, occasionally waving the right hand as if giving advice.

8) Jathil Lampah

a. Telu

Telu is a footwork stepping three times, right foot, left foot and right foot by playing the ebleg head (property of a braided horse).

b. Gedruk

Gedruk is a footstep.

c. Egol

Egol is the movement of the hips, head and hands according to the drum beats and different patterns according to the needs such as playing ebleg or sampur.

9) Senggakan

a. Power Sound

Power sound is a power that is used to channel and emit sound. The energy in question is the sound produced by selfpower, vocal techniques and emotional energy.

b. Vocal

It namely the technique of adjusting the sound with proper breathing so that the sound that is issued sounds beautiful, clear, and pleasant to hear / not false.

10) Musicians

a. Beating

Playing a musical instrument gamelan is sounded way to produce appropriate sound or noise instruments used, such as drums.

b. Hitting

Playing a gamelan instrument by being hit to produce a sound or sound according to the instruments used, for example the gong, kenong, and kempul.

c. Blown
Playing a musical instrument which is used by blowing it to produce sounds or sounds that have high artistic value, for example slompret.

\section{Exercise}

In order to form a Reog Ponorogo player's physical and mental form. Exercise in order to form a physical and mental form of the Reog Ponorogo player is a form of effort to create and improve the physical and mental abilities of the player through predetermined training stages. Forms, types and benefits of physical and mental training of Reog Ponorogo players will be explored through the process of interviewing Reog players and observational observations of the physical exercises carried out.

Physical exercise is an activity that is repeated systematically with the aim of increasing physical and mental abilities. In principle, training is a process of change for the better, namely improving physical quality, body functional ability and psychological or mental quality.

With regard to the physical activity of reog players who have elements of physical abilities and movement skills at the time of the show. The first is a variety of forms of training in singo barong or dhadak merak players, then bujang ganong, klana sewandana, warok, jathil, senggakan, and the last is pengrawit.

\section{a. Singo Barong or Dhadak Merak}

There are several forms of training performed by a singo barong player or dhadak merak. The various forms of physical exercise that are carried out are as follows:

1. Exercises to increase jaw strength used to carry the singo barong or dhadak merak mask can be done by pulling a pulley that has been given a load, weight training by biting a log which has been weighted up and down, chewing fried soybeans up to one jar.

2. Exercises to increase neck muscle strength can be done by moving the neck sper (a kayang position with the head resting back and forth), pulling the pulley that is given the weight.

3. Exercises to increase arm muscle strength can be done with push up exercises.

4. Exercises to increase shoulder muscle strength can be done with pull ups 
5. Exercises to increase back muscle strength can be done with back up

6. Exercises to increase abdominal muscle strength can be done with sit ups

7. Exercises to increase leg muscle strength can be done with running exercises and weight training

\section{b. Bujang Ganong}

There are several different forms of training performed by a single ganong player. The various forms of physical exercise that are performed are as follows:

1. Exercises to increase arm muscle strength can be done with push ups and hand stands.

2. Exercises to increase abdominal muscle strength can be done with sit ups.

3. Exercises to increase back muscle strength can be done with back up and kayang exercises.

4. Exercises to increase leg muscle strength can be done with running and skipping exercises.

5. Exercises to increase flexibility can be done with floor exercises including kayang, whip, roll, cart, somersault exercises.

\section{c. Klana Sewandana}

There are various forms of training performed by aplayer. The various forms of physical exercise that are done are as follows:

1. Exercises to increase arm muscle strength can be done with push ups.

2. Exercises to increase abdominal muscle strength can be done with sit-ups.

3. Exercises to increase back muscle strength can be done with back up exercises.

4. Exercises to increase leg muscle strength can be done with running and skipping exercises.

d. Warok

There are several different forms of training performed by a warok player. The various forms of physical exercise that are done are as follows:

1. Exercises to increase arm muscle strength can be done with push ups.

2. Exercises to increase abdominal muscle strength can be done with sit-ups.
3. Exercises to increase back muscle strength can be done with back up exercises.

4. Exercises to increase leg muscle strength can be done with running and skipping exercises.

5. Exercises to increase flexibility can be done with floor exercises including kayang, whip, roll exercises.

6. Exercises to increase dexterity of martial arts movements can be done with martial arts exercises.

e. Jathil

There are several different forms of training performed by a jathil player. The various forms of physical exercise that are performed are as follows:

1. Exercises to increase arm muscle endurance can be done with dance movement exercises.

2. Exercises to increase leg muscle strength can be done with horse exercises, skipping (jumping rope).

\section{f. Senggakan}

There are several different forms of training performed by a senggakan player. The various forms of physical exercise that are done are as follows: Exercises to improve breathing can be done with vocal exercises.

g. Pengrawit

There are several different forms of training performed by a pengrawit. The various forms of physical exercise that are carried out are as follows:

1. Exercises to increase the strength of the arm muscles used for hitting or beating drums can be done with keplok push ups.

2. Exercises to improve breathing can be done with frequent slomping exercises.

\section{CONCLUSION}

Based on the findings of field data and theoretical discussion, this study can conclude the following matters. First, the traditional arts of Reog Ponorogo are inseparable from activities that have elements of physical activity, namely acrobatics, dancing, singing and playing the gamelan. Physical abilities possessed by reog players include muscle strength, endurance, flexibility, agility and power. Second, exercises to form physically and mentally 
performed by every Reog Ponorogo player are by doing strength training, flexibility / flexibility, agility, basic floor exercises, endurance, and breathing.

\section{REFERENCES}

[1] Ary Donald, Lucy Cheser Jacobs \& Christine K. Sorensen. 2010. Introduction to Research in Education Eighth Edition. Canada: Nelson Education, Ltd.

[2] Krisyanto Agus. 2010. Classroom Action Research. Surakarta: UNS Press.

[3] Moleong. 2011. Qualitative Research Methodology revised edition. Bandung: Rosda Karya.

[4] Sajoto M. 1995. Physical Condition Development in Sports. Surakarta: UNS Press.

[5] Sugiyono. 2016. Quantitative Approach Educational Research Methods, Qualitative and $R \& D$. Bandung: Alfabeta.

[6] Yuliastuti Rima. 2009. Appreciation of the Art of Dance. Jakarta: Pantja Sympathy. 